\title{
ОБРАЗ ОТЦА КАК ЧАСТЬ ЯЗЫКОВОЙ КАРТИНЫ МИРА РЕБЁНКА
}

\section{THE IMAGE OF THE FATHER AS PART OF THE LANGUAGE PICTURE OF THE CHILD'S WORLD}

N. Bykova

Summary: The article discusses the linguistic representation of the image of the father in Russian fiction of the XX century, revealing the theme of childhood. The role of the father in the formation of the worldview of the child, his linguistic picture of the world is analyzed. Children's picture of the world is the basis for the formation of a picture of the world of an adult. In this regard, it is important to trace the manifestation of masculinity in it, which is greatly facilitated by the child's communication with his father. When describing linguistic units, the method of dictionary definitions, contextual analysis is used. The material for the study was the text of the autobiographical novel by I.S. Shmelyov «The Summer of the Lord».

Keywords: language picture of the world, autobiographical story, childhood, child, father image

\author{
Быкова Наталья Николаевна \\ Аспирант, ФГБОУ ВО «Ивановский государственный \\ университет» \\ natkotk@mail.ru
}

Аннотация: В статье рассматривается языковая репрезентация образа отца в русской художественной литературе XX века, раскрывающей тему детства. Анализируется роль отца в формировании мировидения ребёнка, его языковой картины мира. Детская картина мира является основой для становления картины мира взрослого человека. В связи с этим важно проследить в ней проявление маскулинности, которой в значительной степени способствует общение ребёнка с отцом. При описании языковых единиц используется метод словарных дефиниций, контекстуального анализа. Материалом для исследования послужил текст автобиографической повести И.С. Шмелёва «Лето Господне».

Ключевые слова: языковая картина мира, автобиографическая повесть, детство, ребёнок, образ отца.

4. мн. Люди, облеченные властью (устар. и разг.).

5. перен. Тот, кто является родоначальником, основоположником чего-н. (высок.).

6. перен., кому и кого. Человек, по-отечески заботящийся о подчиненных, младших.

7. Обращение к пожилому мужчине или к мужу как к отцу своих детей (прост.).

8. Обычно в сочетании с личным именем. Служитель церкви или монах, а также обращение к нему [3; 707].

В повести «Лето Господне» лексема отец используется в первом значении: Отец, как всегда, бегом, оглядывает бойко [6; 173]. Отец, за делами, о пустяках не думает, и то удивился - справился: что-то нонче скворцов не слышно» [6; 365]. Горкин пальцем даже на отца погрозился, как на меня, не слушаюсь когда» [6; 415]. В речи главного героя повести Вани используется не только слово отец, но и «nапашенька»(ласк.) - «то же, что отец» (в 1 знач.) (Ожегов): Здоров папашенька, прежний совсем, весёлый! [6; 409] Я стал осматриваться, отыскивать: что ещё тут самое главное, самое важное... - от nanaшеньки? [6; 459]

В произведении не так часто возникает конкретное описание внешности отца. Читателю трудно составить портрет, т.к. для мальчика внешность не является главным в образе отца. Ребёнок фокусирует своё внимание 
на деталях образа, его характере: «Редко кричит отец. Случилось что-нибудь важное» [6; 16]. «В кабинете кричит отеи, стучит кулаком и топает» [6; 19]. «Отеи, в сером халате, скучный, - я вижу его нахмуренные брови, - считает деньги» [6; 22]. "Лицо его как-то осветилось, глаза блеснули» [6; 24]. «Выбегает отеи, в халате, взъерошенный, глаза навыкат» [6; 61]. К самому потолку, где сидит в клетке скворушка, смеётся зубами из-под усов» [6; 72]. «Отеч щекочет холодными мокрыми усами» [6; 122]. «Когда он рад чему, всегда скажет и головой мотнёт: «Валяйте!» [6; 409]. «Синяя голова стала у отиа, когда обрили, такой смешной» [6; 431].

Сергей Иванович постоянно находится в движении, он практически не находится дома, поэтому в рассказах о нём у ребёнка присутствует большое количество глаголов. Действие может быть выражено и наречием образа действия: «Отеи, как всегда, бегом, оглядывает бойко» [6; 173], "всё бегает по лестницам через три ступеньки» [6; 372], «песенки, песенки, всё свистит» [6; 372], «на сто делов один, а поспевает» [6; 379].

Образ отца не только визуальный, он содержит и обонятельный компонент. В повествовании автор часто обращает на него внимание. Запах можно назвать одним из средств передачи ощущения окружающего мира, т.к. «каждый запах относителен, сопряжен с той или иной предметно-смысловой сферой, с определенной культурной традицией» [1;60]: «От его пальчев пахнет душистым, афонским, маслом» [6; 72]. «Пахнет от него лошадью и сеном» [6;89]. «Пахнет знакомым фрлердоранжем, снежком, морозом. <...> И я чувствую у щёчки тонкий и сладкий запах чудесной груши, и винограда, и пробковых опилок» [6;122]. Порой обонятельный образ опережает зрительный: «Запах духов и кожи... его запах!... - подняли во мне всё...» [6;460].

Сергей Иванович является бесспорным авторитетом для сына. Ребёнок чувствует себя его преемником. Это выражается в именовании самого Вани: «Отец садится под «траспарат». Рядом Горкин и Василь Василич. Я с другой стороны отиа, как молодой хозяин» [6; 97]. Не только мальчик чувствует себя последователем отца, но и окружающие относятся к нему серьёзно. В тексте это выражено обращением: «Отиа чуть не под руки ведут молодиы, усаживают, любуются. И меня тоже парадно принимают, называют - «молодой хозяин» [6; 409]. Слово «хозяин» и его производные могут произноситься с иронией: «Возьми его, Панкратыч, на ледокольню, всё-таки глаз хозяйский... - смеётся так» [6; 188]. В силу возраста вникнуть в дела отца не получается: «А я братеи, барки какие ухватил в Подольске!... Вырастешь - всё узнаешь. А сейчас мы с тобой кала-чика горяченького...» [6; 89].

Несмотря на то, что Сергей Иванович постоянно занят делами: «Долго они толкуют, а отец всё не замеча- ет, что пришёл я прощаться - ложиться спать» [6; 53], у него с сыном заведён определённый ритуал общения, главное в котором не слова, а действия: «Я прижимаюсь к отиу, к ноге. Он теребит меня за шёку» [6; 72]. «Отеи прихватывает меня за щёку, сажает на колени на диване» $[6 ; 89]$. Несоблюдение негласных правил поведения сразу привлекает внимание Вани: «Так его всё расстроило, что и не ущипнул за щёчку» [6; 22].

Ванин отец занимается делами, поэтому не имеет возможности посвятить много времени воспитанию сына. Иногда из-за этого мальчик лишь находится рядом с отцом, но не общается: «Тебе чего? - спрашивает он строго. - Не мешай. Возьми молитвенник, почитай» [6;22]. «И что ты, братеи, мешать приходишь... - рассеянно говорит отец и начинает смотреть сквозь ширмочки» [6; 87]. Возможно, именно по причине постоянной занятости взрослых, ребёнок противопоставляет себя им: «Они ничего не видят, а я вижу: чудесные звёздочки, другие!» [6; 87]. В момент детской обиды (не взяли с собой в театр, когда заболел) Ване кажется, что все про него забыли, даже отец, который приравнивается в этот момент к другим людям, входящим в окружение Вани. И он находит этому простое объяснение: «В театр не взяли. Маленький я, вот все и обижают. Горкин один жалеет» [6; 149]. Но от этого ценнее становятся моменты, проведённые вместе с отцом: выезд верхом на лошади, посещение крещенской «ердани», поездка в баню, купание птиц. Любое совместное времяпрепровождение вызывает у Вани положительные эмоции: «Прыгает голова Кавказки, грива жёстко хлещет меня в лицо. "Лихо?» - спрашивает отец в макушку, сжимая меня под мышками» [6; 104]. «Впервые везут меня на ердань, смотреть. <...> Мы с отцом едем на беговых, наши на выездных санях» [6; 164]. «Я всё не верю, что поеду сейчас с отиом, - не верю и не верю, топчусь на месте, - может ли быть такая раdocmb!» [6; 403].

Отец приобщает Ваню к вере. Видя благоговение отца перед святынями, сын не просто подражает ему, он проникается его чувствами: Когда зажигает отец - по субботам он сам зажигает все лампадки, - всегда напевает приятно-грустно: «Кресту Твоему поклоняемся, Владыко», - и я напеваю за ним, чудесное: И свято-е... Воскресе-ние Твое Сла-а-вим!» [6;17]. «Отеи надевает летний пиджак и начинает оправлять лампадки. Это он всегда сам: другие не так умеют». Я хожу с ним. На душе у меня радостное и тихое, и хочется отчего-то плакать [6;72]. Чувствуя скорое приближение смерти, Сергей Иванович, уже лишившийся зрения, считает своим долгом благословить детей. Поэтому последние слова, которые услышал сын от отца, были такими: «Ваня это! ... - Сказал он едва слышно, - тебе Святую ... Троичу... мою... - больше я не слыхал. Образ коснулся моей головы и так остался» [6; 466]. Отец благословляет Ваню «своим» образом, которым когда-то благословляли самого Сергея Ивановича. 
Отец Вани хорошо относится к окружающим, независимо от их социального статуса. Такая модель поведения становится образцом: «Я знаю: отец после дедушки совсем молодой остался, Горкин ему во всём помогал - советовал. Я беру его за руку и шепчу: И я тебя всегдавсегда буду слушаться, не буду никогда обижать» [6; 274]. Когда же отец сам сердится на Василь Василича и медлит с примирением, Ваня, чувствуя несправедливость, говорит: «А отец всё не отвечает, и мне за него стыдно» [6; 21]. Очень важно, что, всем сердцем любя Сергея Ивановича, ребёнок понимает, что даже отец может совершить ошибку.

Маленький человек ощущает единение с окружающими: «все и всё были со мною связаны, и я был со всеми связан, от нищего старичка на кухне, зашедшего на «убогий блин», до незнакомой тройки, умчавшейся в темноту со звоном» [6; 169]. Поэтому ему становится не по себе, когда он видит несправедливое отношение к людям, ему хочется это исправить. При этом ребёнок представляет, как бы на его месте поступил самый близкий человек. Когда отец находится при смерти, а родственники не замечают и непроизвольно отталкивают Павла Ермолаевича, Ваня говорит: «Мне стыдно, что его и чайком не угостили. А отец всегда, бывало, и поговорит с ним, изакусить пригласит» [6; 479]. Эти слова сопровождаются действием: мальчик бежит за гостем и извиняется за поведение взрослых.

Тяжёлая болезнь родного человека заставляет ребёнка задуматься о страшном и таинственном - о смерти. О ней Ваня размышлял и раньше. Но в некоторых случаях она не страшна, в разговоре и в мыслях она упоминается вскользь: "Лето у всех, а меня мучают, всё каким-то экзаменом стращают, а до него ещё года два, за два-то года все и помереть успеют, Горкин говорит» [6; 203]. Когда же Ваня говорит с Горкиным о вере, рассматривает картинки, висящие в его комнате, мысли меняют свой ход. На изображениях он видит умирающих праведника и грешника. Мальчик боится за праведника, его пугает мысль о том, что будет, если бесы смогут добраться до его души, несмотря на защиту ангелов. На смерть грешника он боится взглянуть, т.к. душа осталась без защиты добрых сил.

Страшные мысли возвращаются к Ване даже в церкви: «Оглядываюсь - и вижу отиа. Он стоит у Распятия. И мне уже не страшно: он здесь, со мной. И вдруг ужасная мысль: умрёт и он!... Все должны умереть, умрёт и он» [6; 32]. Мальчика пугает не столько собственная смерть, сколько смерть близкого человека. Но при этом ребёнок ощущает смерть как что-то далёкое, невозможное, что никак не должно затронуть его отца, который является молодым мужчиной. Для него в этот момент понятия молодость и жизнь синонимичны. «Ломшакову - сколько раз говорили все - жить не больше месяча остаётся, сердие пропил, - а он всё жив... а папашенька, молодой, здоровый, вина никогда не пил» [6; 492]. Осознание приближения смерти самого дорогого человека приходит постепенно. В это трудно поверить: «Господи, неужели умирает?... вот сейчас, там?» [6; 486].

Ребёнок, находясь в состоянии, близком к болезни, отмечает для себя перемены даже в именовании отца, что пугает его: «Теперь говорят усопший, а не «папашенька», не «Сергей Иванович». В этом слове, чужом мне, чу-

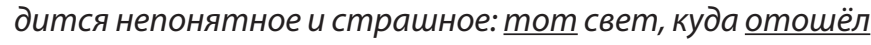
отец» [6; 489].

Образ отца в сознании главного героя связан с самыми светлыми воспоминаниями. Для Вани отец является символом детства. С уходом отца из жизни он связывает и конец беззаботной поры, конец детства: Там он - отец мой... Я знаю: это последнее прощанье, прощанье с родимым домом, со всем, что было [6; 498].

По результатам проведённого анализа автобиографической повести И.А. Шмелёва «Лето Господне» можно сделать вывод о том, что образ отца передаётся через призму детского восприятия, поэтому акценты часто делаются на деталях. Для Сергея Ивановича характерны доброта, искренность, порядочность. Он заботится об окружающих, любит природу, хранит веру в своей чистой душе. Семья главного героя живёт по христианским традициям, согласно которым отец является главой семьи. Образу отца в повести отведено центральное место, а образ матери упоминается редко, он практически лишён детализации. Причина этого кроется в личных детских воспоминаниях Ивана Шмелёва, в которых мать ассоциируется с наказанием за провинности и даже за их отсутствие. Поэтому автор описывает мужские образы, которые дороги ему: отец, Горкин.

Образ отца передаётся на страницах книги с помощью следующих лексем: отеи, папашенька, весёлый, молодой, смеётся, бежать. В речи функционирует субстантивная, адъективная, глагольная лексика. Образ отца оказывает большое влияние на становление личности ребёнка, что отражается и на содержании языковой картины мира.

\section{ЛИТЕРАТУРА}

1. Костяев А.И. Ароматы и запахи в истории культуры: знаки и символы. Москва: Стереотип, 2020. 144 с.

2. Манёров Р.В. Образ себя как отца в структуре я-концепции мужчин: автореф. дис. канд. психол. Наук. Санкт-Петербург, 2013. 
3. Ожегов С.И. Толковый словарь русского языка: Ок.100000 слов, терминов и фразеологических выражений / под ред. проф. Л.И. Скворцова. Москва: 000 «Издательство Оникс»: 000 «Издательство «Мир и Образование», 2009. 1360 с.

4. Паршина И.В. Роль отца в воспитании сына // Вопросы дошкольной педагогики. 2017. №2 (8). С. $42-45$.

5. Сальникова В.В. Экспериментальное изучение языковой картины мира ребёнка (на материале ассоциаций к слову «отец» // Филологические науки. Вопросы теории и практики. 2017. №7 (73): В 3 х ч. Ч. 3. С. 174-177.

6. Шмелёв И.С. Лето Господне. Москва : Детская литература, 2006.527 с.

7. Штейнбах К.В. Образ отца и тема отцовства в творчестве 3. Прилепина: Роман «Санькя» и сборник повестей «Восьмёрка» // Вестник ВГУ. Серия: Филология. Журналистика. 2014. №4. С. 68-70.

○ Быкова Наталья Николаевна (natkotk@mail.ru).

Журнал «Современная наука: актуальные проблемы теории и практики»

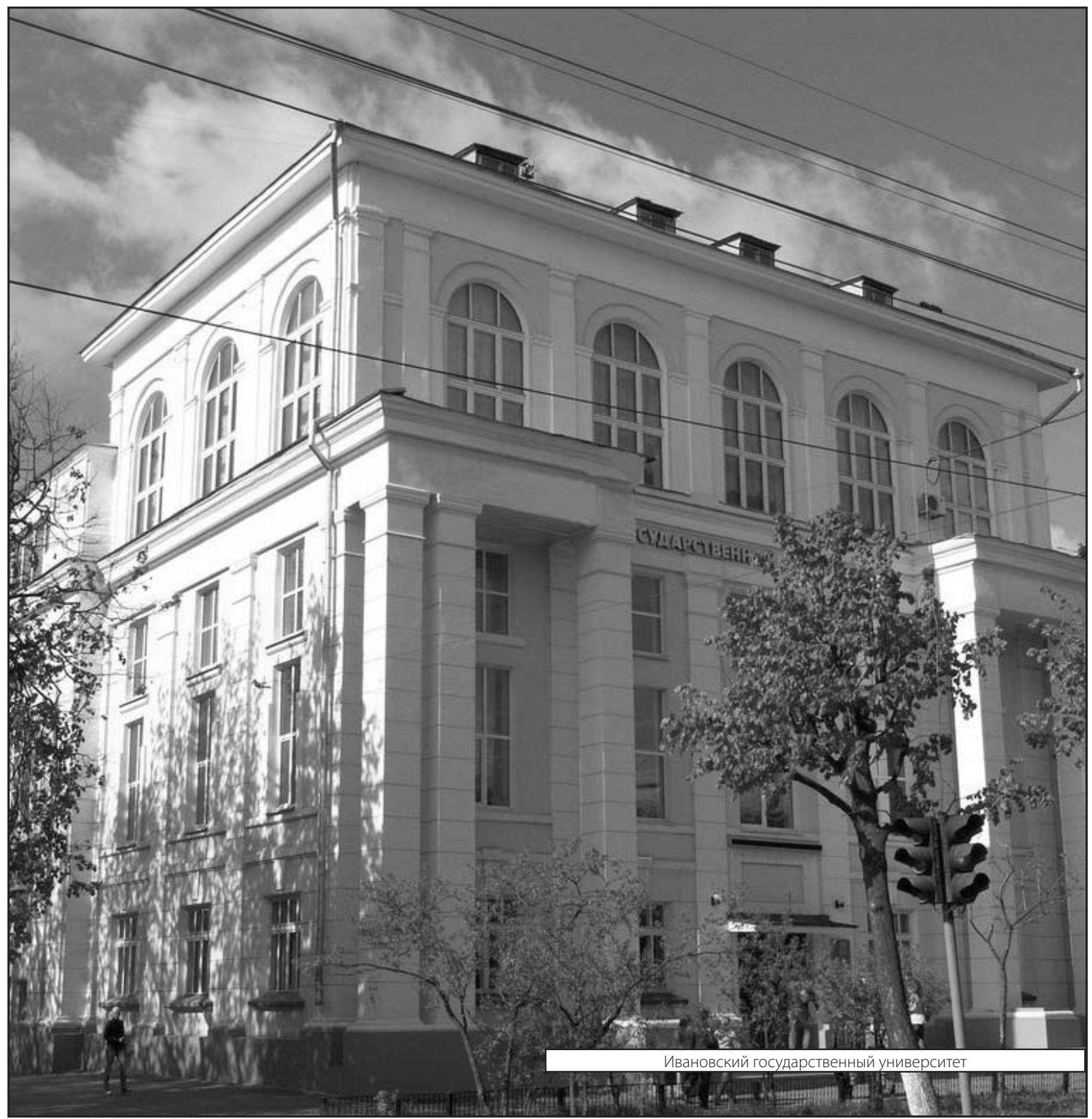

